\title{
Lipophilic phytochemicals from sugarcane bagasse and straw
} \author{
Jorge L. Colodette ${ }^{\mathrm{c}}$, Ana Gutiérrez ${ }^{\mathrm{a}}$ \\ a Instituto de Recursos Naturales y Agrobiología de Sevilla, CSIC, P.O. Box 1052, E-41080 Seville, Spain \\ ${ }^{\mathrm{b}}$ Department of Chemistry, Federal University of Viçosa, Viçosa, MG 36570-000, Brazil \\ c Department of Forestry Engineering, Federal University of Viçosa, Viçosa, MG 36570-000, Brazil
}

José C. del Río ${ }^{\mathrm{a}, *}$, Gisela Marques ${ }^{\mathrm{a}}$, Alessandro G. Lino ${ }^{\mathrm{a}, \mathrm{b}}$, Cláudio F. Lima $^{\mathrm{b}}$,

\section{A R T I C L E I N F O}

\section{Article history:}

Received 19 March 2015

Received in revised form

17 September 2015

Accepted 28 September 2015

\section{Keywords:}

Sugarcane bagasse

Sugarcane straw

Aldehydes

Alcohols

Fatty acids

Sterols

\begin{abstract}
A B S T R A C T
The composition of lipophilic phytochemicals in sugarcane bagasse and straw, the two major residues of sugarcane processing, was investigated in detail by gas chromatography and mass spectrometry. The composition of the lipids from sugarcane bagasse and straw was completely different from each other. While the extracts of sugarcane bagasse were dominated by $n$-aldehydes (ca. $48 \%$ of all identified lipids) and $n$-fatty alcohols (ca. 23\%) with lower amounts of $n$-fatty acids (10\%) and steroid ketones (14\%), the extracts from sugarcane straw were strongly dominated by $n$-fatty acids (accounting for ca. $60 \%$ of all identified compounds) with significant amounts of steroid compounds, particularly sterols (10\%) and steroid ketones (14\%). Tocopherols and triterpenols were also found, being particularly abundant among the extractives of sugarcane straw. Sugarcane bagasse and straw can thus be considered as promising feedstocks for obtaining highly valuable phytochemicals of nutraceutical or pharmaceutical interest.
\end{abstract}

(c) 2015 Elsevier B.V. All rights reserved.

\section{Introduction}

Sugarcane (Saccharum spp.) is a perennial monocot plant belonging to the grass family (Poaceae). Sugarcane is an important economic plant in many countries as it is the main feedstock for the production of sugar as well as ethanol, with Brazil leading the world production (Goldemberg, 2008; Santos et al., 2012; De Souza et al., 2014). The plant originated from Asia but it is well adapted to most tropical and subtropical climates, where it is one of the most important bioenergy crops. The production of sugar from sugarcane generates two main types of wastes, the fibrous residue after extraction of the juice (named bagasse), and the left over harvest residues (straw). These sugarcane wastes are produced in large quantities, about 280 million tons of bagasse and straw per year (Ortiz and de Oliveira, 2014), and they are likely to increase in the near future as this crop expands and new industrial plants are implemented. Currently, sugarcane residues are mostly burned for the production of heat and electricity at the sugar factory. However, they could also be used as feedstocks for the production of other

\footnotetext{
* Corresponding author. Fax: +34 954624002.

E-mail addresses: delrio@irnase.csic.es (J.C. del Río), gisela@irnase.csic.es (G. Marques), aguarinolino@yahoo.com.br (A.G. Lino), cflima@ufv.br (C.F. Lima), colodett@ufv.br (J.L. Colodette), anagu@irnase.csic.es (A. Gutiérrez).
}

high-value products in the context of the lignocellulosic biorefinery.

Sugarcane bagasse and straw are basically composed of cellulose, hemicelluloses and lignin, but also contain significant amounts of lipids (ca. 1-2\% by weight) that can be extracted to obtain high-value products. Plant lipids are a particular group of phytochemicals - chemical compounds that occur naturally in plants - that include different classes of compounds (i.e., alkanes, fatty alcohols, fatty acids, free and conjugated sterols, terpenoids and triglycerides) and have a wide range of industrial applications in food, cosmetic and pharmaceutical industries (Hernandez, 2005 Metzger and Bornscheuer, 2006). Several studies have highlighted the interest of exploiting the lipids from lignocellulosic residues as rich sources of valuable compounds, as is the case of lipophilic extractives isolated from organosolv liquors (Villaverde et al., 2010) or phenolic compounds extracted from several waste materials such as barks and knotwoods (Pietarinen et al., 2006).

The composition of lipids of sugarcane plants has been the subject of several investigations and several compounds, including triterpenoids and steroids (Ohmoto et al., 1970; Deshmane and Dev, 1971; Feng et al., 2014a,b), or aliphatic components such as longchain alcohols (polycosanol) and aldehydes (Purcell et al., 2005; Asikin et al., 2012), have been reported. On the other hand, the lipid composition of sugarcane waxes recovered from different sugarcane mill by-products such as the filter cake from sugar refinery or from fermentation wastes and vinasses from alcohol distilleries 
and rum factories, have also been documented (Nuissier et al., 2002; Georges et al., 2006; de Lucas et al., 2007). However, studies concerning the composition of lipids in the two major solid wastes generated by the sugar and alcohol industry, sugarcane bagasse and straw, have not been performed so far. Therefore, in this paper we performed a comprehensive characterization of the lipophilic compounds present in sugarcane bagasse and straw by the use of gas chromatography (GC) and gas chromatography-mass spectrometry (GC-MS) using short- and medium-length high temperature capillary columns, respectively, with thin films, which enables the elution and analysis of a wide range of compounds from fatty acids to intact high molecular weight lipids such as sterol glycosides (Gutiérrez et al., 1998). This study can provide significant further knowledge about the composition of lipids in these sugarcane residues, which can be used as valuable sources of active phytochemicals.

\section{Materials and methods}

\subsection{Samples}

Sugarcane plants (Saccharum spp. hybrids; UFV/RIDESA RB867515 variety) were collected at harvesting age (approximate 6 months-old) from high performance sugarcane plantations (geographical coordinates $20^{\circ} 10^{\prime} 0^{\prime \prime}$ South, $42^{\circ} 31^{\prime} 0^{\prime \prime}$ West, altitude of $373 \mathrm{~m}$ ). Sugarcane bagasse and straw were supplied by a mid-size ethanol mill located in the São Pedro dos Ferros county, MG, Brazil. The processing of sugarcane involved two steps. The first was the crushing of sugarcane stalks in a semi-industrial chipper; then the fragments were processed by milling to extract the sugarcane juice. The resulting residue (bagasse) was used for the subsequent characterization studies. Straw, a heterogeneous material composed of leaves and tops of sugarcane, was crushed in the same equipment used to grind the stalks in order to improve the homogenization of the material. The sugarcane residues were air-dried and milled in an IKA knife mill (Janke and Kunkel, Analysenmühle) for subsequent analyses. The acetone extractives content in both residues were determined by Soxhlet extraction with acetone for $16 \mathrm{~h}$. The acetone extracts were then evaporated to dryness, and resuspended in chloroform for additional chromatographic analysis of the lipidic fraction. The contents of water soluble material, Klason lignin, acid-soluble lignin, holocellulose, $\alpha$-cellulose and ash were determined according to the methods published elsewhere (del Río et al., 2015).

\subsection{GC and GC-MS analyses}

The GC analyses were performed in an HP 5890 gas chromatograph (Hewlett Packard, Hoofddorp, Netherlands) equipped with a split-splitless injector (temperature set at $300^{\circ} \mathrm{C}$ ) and a flame ionization detector (temperature set at $350^{\circ} \mathrm{C}$ ) and using a short-length high-temperature fused silica capillary column (DB5-HT, $5 \mathrm{~m} \times 0.25 \mathrm{~mm}$ I.D., $0.1 \mu \mathrm{m}$ film thickness; from J\&W Scientific). The oven was temperature-programmed from $100^{\circ} \mathrm{C}$ ( $1 \mathrm{~min}$ ) up to $350{ }^{\circ} \mathrm{C}$ at a rate of $15^{\circ} \mathrm{C} \mathrm{min}^{-1}$ and held to the maximum temperature until the end of the analysis. Helium was used as the carrier gas. Peaks were quantified by area, and the following authentic standards were used to elaborate calibration curves: octadecane (Sigma-Aldrich, 99\%), palmitic acid (Sigma-Aldrich, 99\%), oleic acid (Sigma-Aldrich, $\geq 99 \%$ ), linoleic acid (Sigma-Aldrich, $\geq 99 \%$ ), hexadecanol (Sigma-Aldrich, $\geq 97 \%$ ), sitosterol (Calbiochem, 98\%), stigmasterol (Sigma-Aldrich, 95\%), sitosteryl 3 $\beta$-D-glucopyranoside (Matreya LLC, a mixture of three steryl glucosides of $98 \%$ purity, of which $56 \%$ correspond to sitosteryl glucoside), cholestan-3-one (Sigma-Aldrich, 99\%) and cholesta-3,5-diene (Sigma-Aldrich, $\geq 93 \%$ ). Quantification of individual compounds was performed by using response factors of the same or a similar compound (in the case of triterpenols and alkylresorcinols, for which no standards were available, they were quantified against sitosterol). The data from three replicate samples were averaged.

The GC-MS analysis were performed on a Saturn 4000 (Varian, Walnut Creek, CA) ion-trap equipment fitted with a medium-length high-temperature capillary column (DB5-HT, $15 \mathrm{~m} \times 0.25 \mathrm{~mm}$ i.d., $0.1 \mu \mathrm{m}$ film thickness; from J\&W Scientific). Helium was used as carrier gas at a rate of $2 \mathrm{~mL} / \mathrm{min}$. The samples were injected with an autoinjector (Varian 8200) directly onto the column using a septum-equipped programmable injector system, that was programmed from $60^{\circ} \mathrm{C}(0.1 \mathrm{~min})$ to $380^{\circ} \mathrm{C}$ at a rate of $200^{\circ} \mathrm{C} \mathrm{min}-1$ and held at the maximum temperature until the end of the analysis. The oven temperature was programmed from $120^{\circ} \mathrm{C}(1 \mathrm{~min})$ to $380^{\circ} \mathrm{C}(5 \mathrm{~min})$ at a rate of $10^{\circ} \mathrm{C} \mathrm{min}^{-1}$. The temperature of the transfer line was set at $300^{\circ} \mathrm{C}$ during the analysis. Derivatization with bis(trimethylsilyl) trifluoroacetamide (BSTFA, from Supelco) to form the respective trimethylsilyl (TMS) derivatives was used when required. Compounds were identified by comparing their retention times and mass spectra with those of authentic standards, except for alkylresorcinols and triterpenols, which were tentatively identified by comparing their mass spectra with those reported in the literature.

\section{Results and discussion}

\subsection{Composition of the main constituents of sugarcane bagasse and straw}

The abundance of the main constituents (water soluble material, acetone extractives, Klason lignin, acid-soluble lignin, holocellulose, $\alpha$-cellulose, and ash) of the sugarcane bagasse and straw samples selected for this study are shown in Table 1 . The composition is in the range of values previously published for similar samples, except for the much higher content of extractives reported in previous papers (Rocha et al., 2015). In this study, the lipid compounds (acetone extractives) accounted for $0.9 \%$ in sugarcane bagasse and $1.4 \%$ in sugarcane straw. The extractives content reported by other authors displayed a wide variability; thus, some authors reported extractives content in sugarcane bagasse in the range from 2.3-10.5\% (Rocha et al., 2015), whereas others reported extractives content in the range from 4.3-9.9\% (Benjamin et al., 2014). In sugarcane straw, the extractives content was reported to be as high as 5.9\% (Oliveira et al., 2014). However, these high values are mostly due to the solvents used for the extractives content determination, usually ethanol (95\%) that may also extract low-molecular-weight carbohydrates, salts, polyphenols and other water-soluble compounds.

Table 1

Abundance of the main constituents (\% dry-weight) of sugarcane (Saccharum spp.) bagasse and straw.

\begin{tabular}{lll}
\hline & Sugarcane bagasse $^{\mathrm{a}}$ & ${\text { Sugarcane } \text { straw }^{\mathrm{a}}}^{\mathrm{a}}$ \\
\hline Water-soluble material & $1.3 \pm 0.2$ & $2.1 \pm 0.2$ \\
Acetone extractives & $0.9 \pm 0.1$ & $1.4 \pm 0.1$ \\
Klason lignin $^{\mathrm{b}}$ & $17.8 \pm 0.6$ & $17.0 \pm 0.2$ \\
Acid-soluble lignin & $2.2 \pm 0.2$ & $1.9 \pm 0.2$ \\
Holocellulose $(\alpha$-cellulose) & $75.8 \pm 0.5(40.1 \pm 0.2)$ & $72.9 \pm 0.7(37.9 \pm 0.3)$ \\
Ash & $2.0 \pm 0.1$ & $4.7 \pm 0.5$ \\
\hline
\end{tabular}

a Average of three replicates.

b Corrected for proteins and ash. 

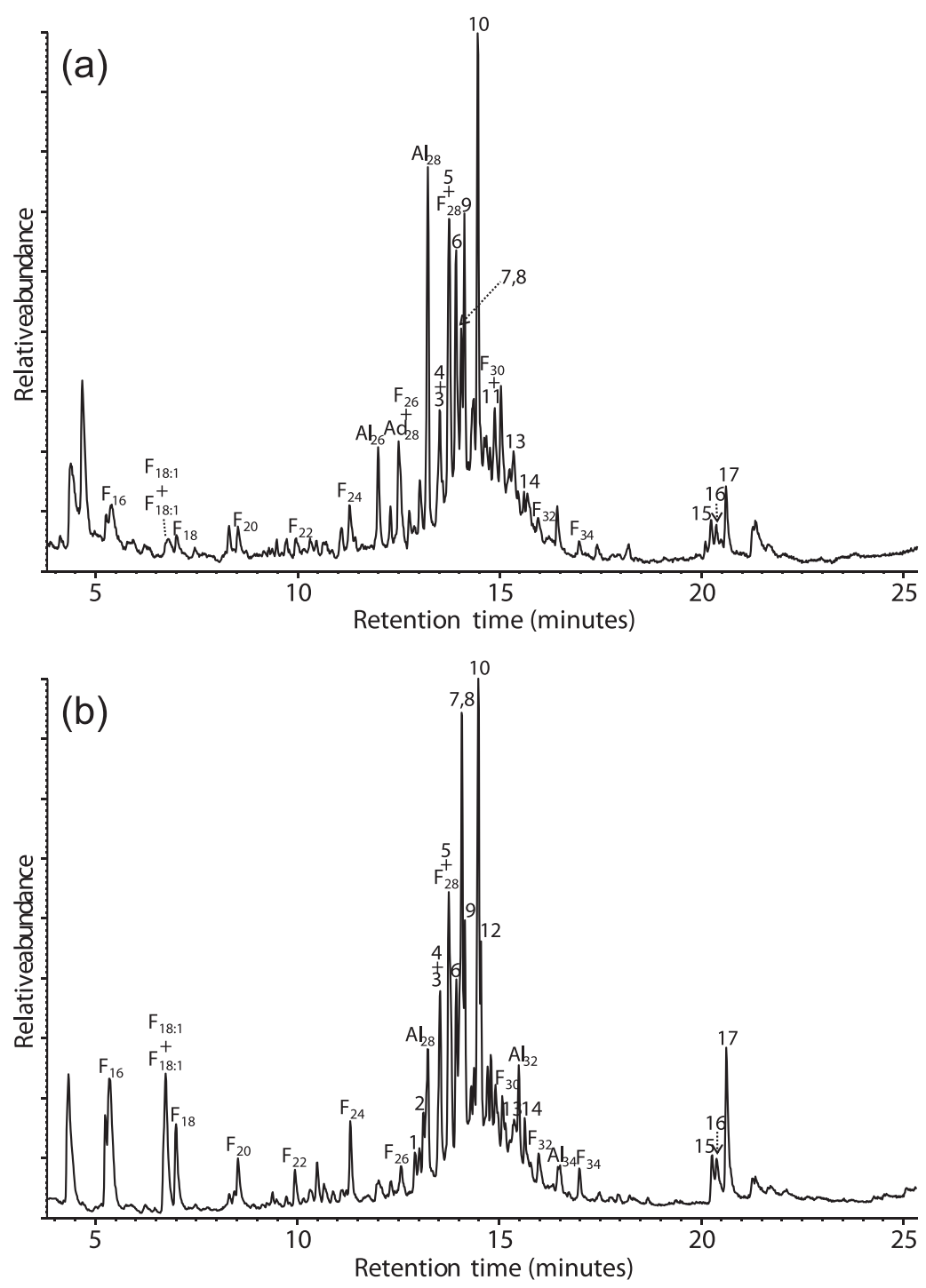

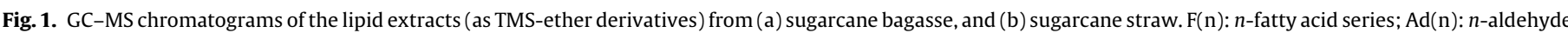

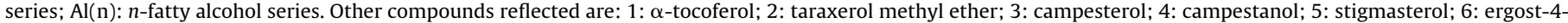

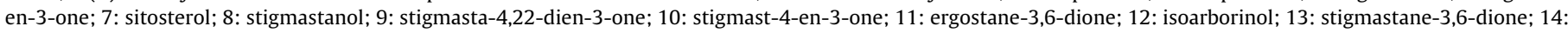
7-oxo-sitosterol; 15 : campesteryl- $\beta$-D-glucopyranoside; 16 : stigmasteryl- $\beta$-D-glucopyranoside; 17 : sitosteryl- $\beta$-D-glucopyranoside.

\subsection{Lipid composition of sugarcane bagasse and straw}

The detailed analysis of the chemical composition of the lipidic compounds in sugarcane bagasse and straw was accomplished by GC and GC-MS (both underivatized and after preparation of the trimethylsilyl-ether derivatives) according to the method previously described (Gutiérrez et al., 1998). The chromatographic conditions used for the analyses, by using short- and mediumlength high-temperature capillary columns with thin films, allow for the elution of a wide range of compounds, from low-molecularweight free fatty acids and sterols to intact high molecular weight lipids, such as sterol glycosides, that are usually biased in more standard GC conditions.

The GC-MS chromatograms of the lipids (as their TMS-ether derivatives) extracted from sugarcane bagasse and straw are shown Fig. 1. A large number of compounds were identified among the acetone extractives, which were subsequently quantified using the appropriate standards. The identities and abundances $(\mathrm{mg} / \mathrm{kg}$, dry, ash-free basis) of the main lipid compounds identified in the acetone extracts of sugarcane bagasse and straw are listed in Table 2. Structures representative of the main classes of lipids identified in sugarcane bagasse and straw, including aliphatic and steroid/triterpenoid compounds, are shown in Figs. 2 and 3 respectively. The predominant lipids identified among the acetone extracts of sugarcane bagasse and straw were series of long-chain fatty acids, alcohols, aldehydes, together with steroids (sterols, sterol glycosides, steroid hydrocarbons and ketones), triterpenols, tocopherols, and lower amounts of $n$-alkylresorcinols and high molecular weight esters. Fig. 4 shows the percentages of the main lipid classes identified in the acetone extracts of sugarcane bagasse and straw. The analyses revealed that the composition of the lipids from sugarcane bagasse and straw were completely different from each other. While the acetone extracts of sugarcane bagasse were dominated by $n$-aldehydes (ca. $48 \%$ of all identified lipids) and $n$-fatty alcohols (ca. 23\%), together with significant amounts of $n$ fatty acids (10\%) and steroid ketones (14\%), the acetone extracts from sugarcane straw were largely dominated by $n$-fatty acids (accounting for ca. 60\% of all identified compounds) with significant amounts of steroid compounds, particularly free sterols (10\%) and steroid ketones (14\%). 


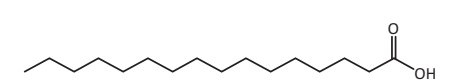

(I)

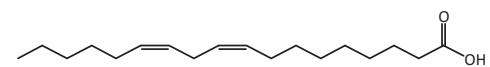

(III)

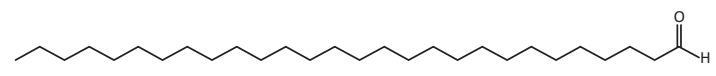

(IV)

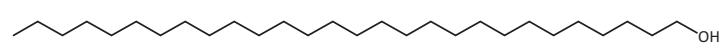

(V)

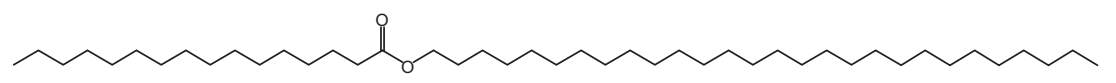

(VI)
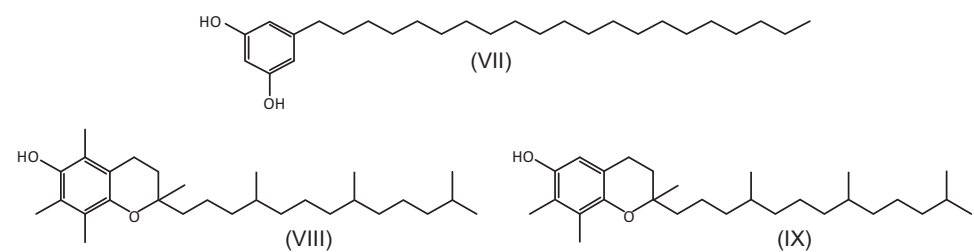

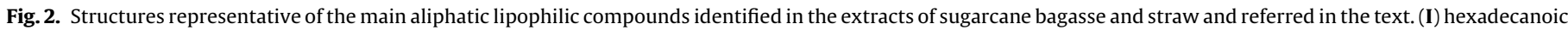

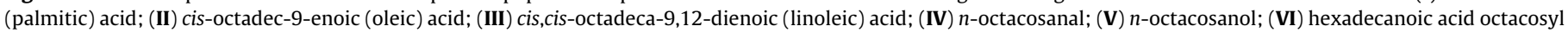
ester; (VII) 5- $n$-heneicosylresorcinol; (VIII) $\alpha$-tocopherol; (IX) $\gamma$-tocopherol.

\subsubsection{Aliphatic series}

The main aliphatic series identified among the lipophilic extractives of sugarcane bagasse and straw were series of long-chain fatty acids, alcohols and aldehydes. The distributions of these aliphatic series in the extracts of sugarcane bagasse and straw are represented in the histograms of Fig. 5. It is clear that while the distribution of long-chain alcohols and aldehydes are similar in both sugarcane residues, the distribution of fatty acids in bagasse and straw was quite different.

Long-chain fatty acids were the most abundant family of lipids identified in sugarcane straw, accounting for $1210 \mathrm{mg} / \mathrm{kg}$, but were present in only minor amounts in sugarcane bagasse $(140 \mathrm{mg} / \mathrm{kg}$ ). In both sugarcane residues, the series of free fatty acids were found in the range from $n$-hexadecanoic acid $\left(C_{16}\right.$, palmitic acid, $\left.\mathbf{I}\right)$ to $n$ tetratriacontanoic acid $\left(C_{34}\right)$, with a strong predominance of the even carbon atom number homologues, although the distribution of the fatty acid series was different in sugarcane bagasse and straw. The series of fatty acids in sugarcane bagasse presented a unimodal distribution with a maximum for $n$-octacosanoic acid $\left(\mathrm{C}_{28}\right)$ that accounts for $60 \mathrm{mg} / \mathrm{kg}$, whereas the fatty acid series in sugarcane straw presented a bimodal distribution, with a maximum for $n$-hexadecanoic acid ( $246 \mathrm{mg} / \mathrm{kg}$ ) and a second maximum for $n$-octacosanoic acid $(160 \mathrm{mg} / \mathrm{Kg})$, and with the occurrence of important amounts of the unsaturated cis-octadec-9-enoic (oleic acid, II, $210 \mathrm{mg} / \mathrm{Kg}$ ) and cis,cis-octadeca-9,12-dienoic (linoleic acid, III, $86 \mathrm{mg} / \mathrm{Kg}$ ) acids, as well as the saturated $n$-octadecanoic acid (stearic acid, $160 \mathrm{mg} / \mathrm{kg}$ ). Unsaturated fatty acids, however, were present in almost negligible amounts in sugarcane bagasse.

The series of $n$-aldehydes was identified in high amounts among the acetone extractives of sugarcane bagasse and represented the most important aliphatic series in this waste material, accounting for $700 \mathrm{mg} / \mathrm{kg}$, but was present in far lower amounts in the extracts of sugarcane straw (only $40 \mathrm{mg} / \mathrm{kg}$ ). In both cases, the series were found in the range from $n$-docosanal $\left(C_{22}\right)$ to $n$-triacontanal $\left(C_{30}\right)$, with the exclusive occurrence of the even carbon atom numbered homologs, and with $n$-octacosanal $\left(\mathrm{C}_{28}\right.$, IV) being the most predominant compound in the series, accounting for up to $480 \mathrm{mg} / \mathrm{kg}$ in sugarcane bagasse and only for $30 \mathrm{mg} / \mathrm{kg}$ in sugarcane straw. Other papers have also identified a series of aldehydes, in the range from $n$-hexacosanal $\left(C_{26}\right)$ to $n$-triacontanal $\left(C_{30}\right)$, with octacosanal $\left(C_{28}\right)$ being the most abundant, in the waxes from different sugarcane cultivars (Asikin et al., 2012).

The series of fatty alcohols were predominant among the lipophilic extractives of sugarcane bagasse $(330 \mathrm{mg} / \mathrm{kg}$ ), but were present in only minor amounts in sugarcane straw $(85 \mathrm{mg} / \mathrm{kg})$. In both cases, the series of fatty alcohols ranged from $n$-tetracosanol $\left(\mathrm{C}_{24}\right)$ to $n$-tetratriacontanol $\left(\mathrm{C}_{34}\right)$, with the exclusive presence of the even carbon atom number homologs and with n-octacosanol $\left(\mathrm{C}_{28}, \mathbf{V}\right)$ as the most prominent compound in the series, accounting for $194 \mathrm{mg} / \mathrm{kg}$ in sugarcane bagasse and $48 \mathrm{mg} / \mathrm{kg}$ in sugarcane straw. Other papers have also identified a series of fatty alcohols in the range from $n$-docosanol $\left(C_{22}\right)$ to $n$-triacontanol $\left(C_{30}\right)$, with $n$ octacosanol $\left(\mathrm{C}_{28}\right)$ being the most abundant, in the waxes of different sugarcane cultivars (Asikin et al., 2012), as well as in sugarcane filter muds (de Lucas et al., 2007). This group of long-chain alcohols is commonly referred as to polycosanol, a product with nutraceutical and pharmaceutical properties, including reduction of platelet aggregation, reduction of low-density lipoprotein levels in blood, inhibition of cholesterol synthesis and prevention of atherosclerosis development (Asikin et al., 2012; Arruzazabala et al., 2002; Noa and Mas, 2005; Singh et al., 2006). Interestingly, the distribution of the long-chain alcohol series parallels that of aldehydes, as usually occurs in the plant kingdom and observed in other plants (Gutiérrez and del Río, 2003; del Río et al., 2013a) suggesting that aldehydes are intermediates in the biosynthesis of alcohols from fatty acids (Tulloch, 1976; Bianchi, 1995).

A series of high molecular weight esters also occurred in the extracts of sugarcane bagasse and straw although in minor amounts ( $5 \mathrm{mg} / \mathrm{kg}$ in bagasse and $8 \mathrm{mg} / \mathrm{kg}$ in straw). The high molecular weight esters were found in the range from $C_{42}$ to $C_{46}$ with the exclusive occurrence of the even atom carbon number homologs, and the $\mathrm{C}_{44}$ analogs being the most abundant ones in both sugarcane residues. A close examination of the mass spectra of the ester peaks indicates that each chromatographic peak is a mixture of several long-chain fatty acids esterified to different long-chain fatty alcohols, with a strong predominance of octacosanol. The $\mathrm{C}_{44}$ 
<smiles>CCC(CCC(C)C(C)C)C1CCC2C3CC=C4CC(O)CCC4(C)C3CCC12C</smiles>

(X)

(XI)

(XII)

(XIII)

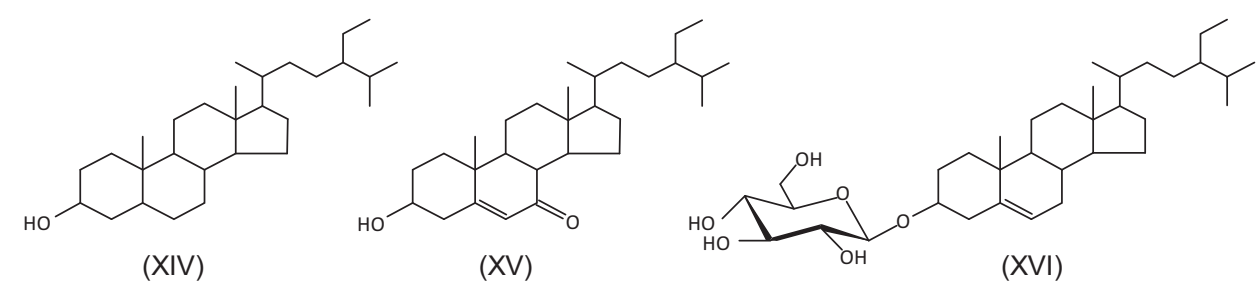

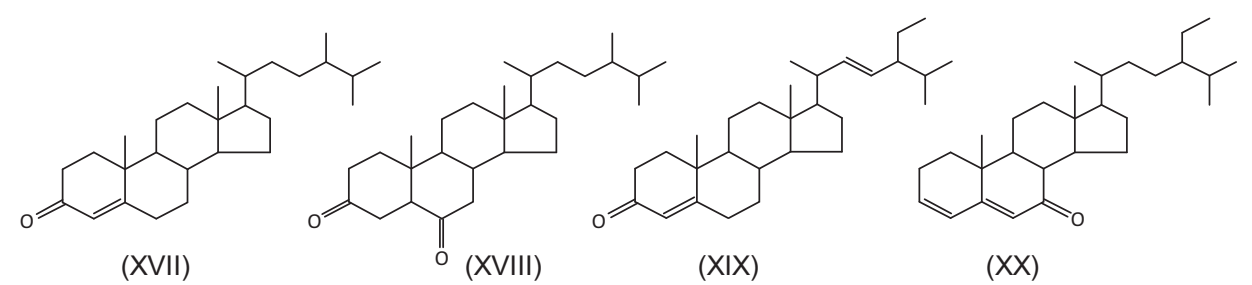<smiles>CCC(CCC(C)C1CCC2C3CCC4=CC(=O)CCC4(C)C3CCC12C)C(C)C</smiles>

(XXI)<smiles>COC1CCC2(C)C3CCC4(C)C5=CCC6CCC(C)(C)CC6C(C)(CCC4C5(C)C)C3CCC2C1(C)C</smiles><smiles>CCC(CCC(C)C1CCC2C3CC(O)C4CC(=O)CCC4(C)C3CCC12C)C(C)C</smiles><smiles></smiles>

(XXV)<smiles>CCC(/C=C/C(C)C1CCC2C3CC=C4C=CCCC4(C)C3CCC12C)C(C)C</smiles>

(XXIII)<smiles>CC(C)C1CCC2C1CCC1(C)C3CCC4C(C)(C)C(O)CCC4(C)C3CCC21C</smiles>

(XXVI)

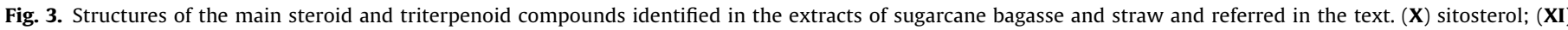

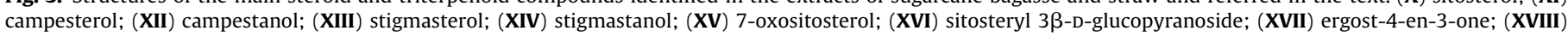

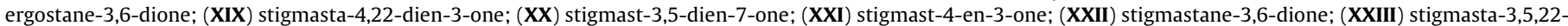
triene; (XXIV) taraxerol methyl ether (crusgallin); (XXV) arundoin; (XXVI) isoarborinol.

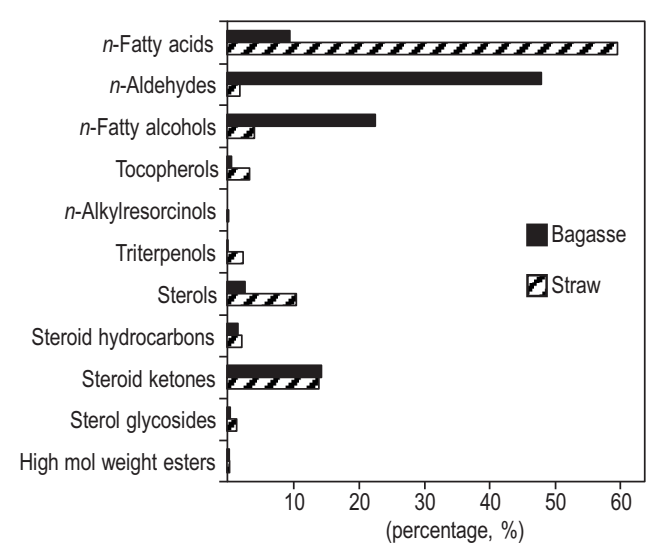

Fig. 4. Percentages of the main lipid classes identified in the acetone extracts of sugarcane bagasse and straw. ester was then predominantly constituted by hexadecanoic acid octacosanyl ester (VI).

\subsubsection{Alkylresorcinols}

A series of 5- $n$-alkylresorcinols could be identified among the lipids of sugarcane straw, although in low amounts $(5 \mathrm{mg} / \mathrm{kg})$, but was completely absent among the lipids of sugarcane bagasse. The identification of 5- $n$-alkylresorcinols was achieved from their mass spectra that show a base peak due to the McLafferty rearrangement at $m / z 268$, characteristic of these molecules (Zarnowski et al., 2002; Gunenc et al., 2013; Prinsen et al., 2014). The series of 5 - $n$-alkylresorcinols ranged from 5 - $n$-nonadecyl $\left(C_{19}\right)$ to $5-n$ tricosylresorcinol $\left(\mathrm{C}_{23}\right)$, with the sole occurrence of the odd carbon atom-numbered homologs, and with 5-n-heneicosylresorcinol $\left(C_{21}\right.$, VII $)$ being the most abundant one $(3 \mathrm{mg} / \mathrm{kg})$. The occurrence of alkylresorcinols has been widely reported in grasses, particularly in cereal grains (Zarnowski et al., 2002; Gunenc et al., 2013; Prinsen et al., 2014; del Río et al., 2013b). 

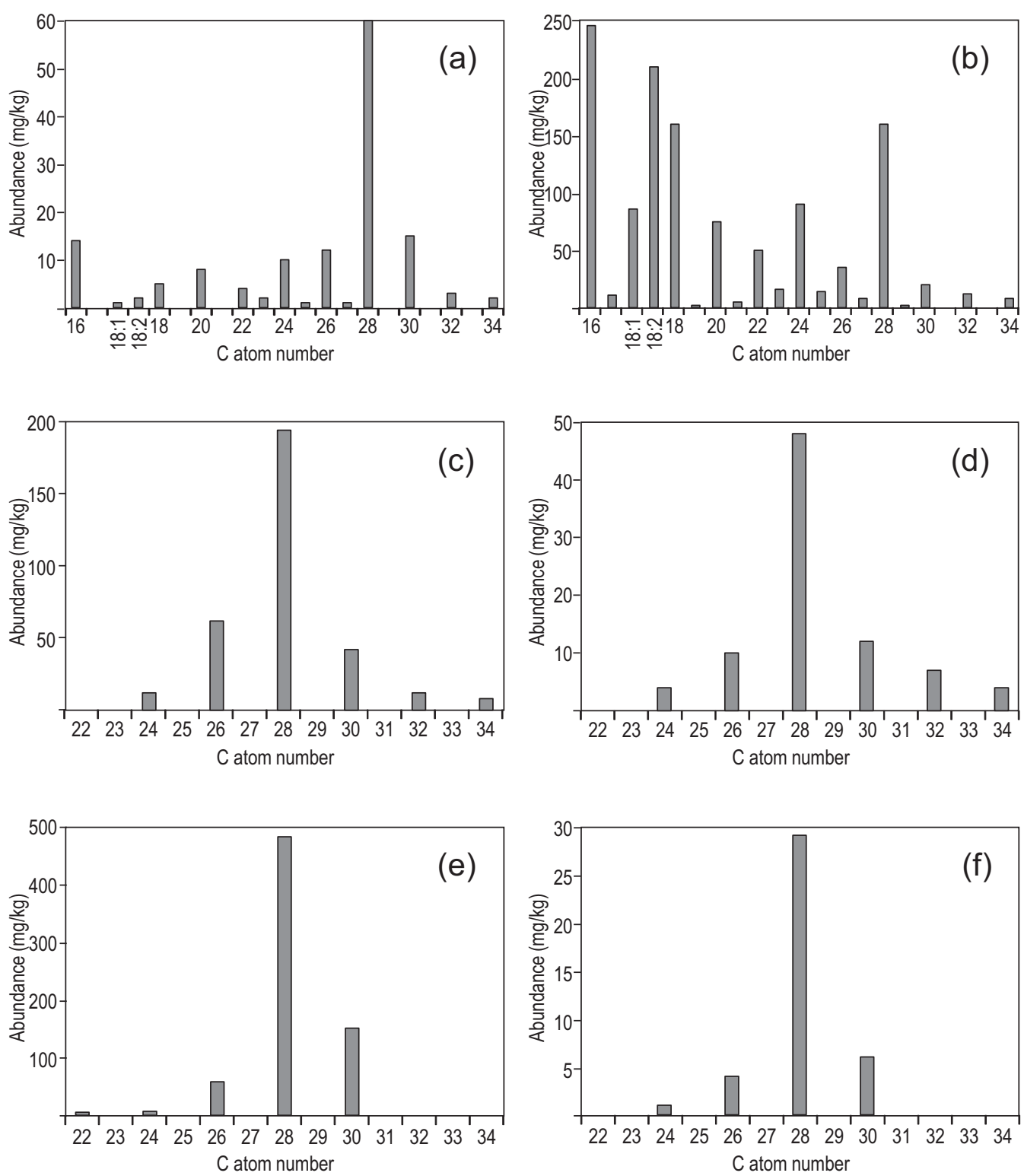

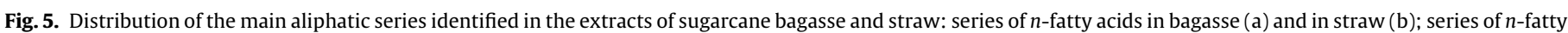

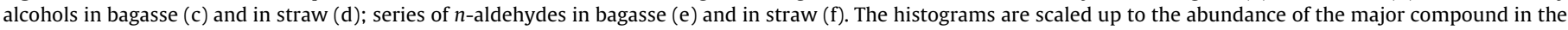
series.

\subsubsection{Tocopherols}

Tocopherols ( $\alpha$-tocopherol, VIII, and $\gamma$-tocopherol, IX) were identified in significant amounts among the lipophilic extractives of sugarcane straw, accounting for $70 \mathrm{mg} / \mathrm{kg}$, and with a predominance of $\alpha$-tocopherol. However, only $\alpha$-tocopherol could be identified in the extracts of sugarcane bagasse, although in lower amounts $(10 \mathrm{mg} / \mathrm{kg})$, whereas no traces of $\gamma$-tocopherol could be detected. Tocopherols were identified based on their characteristic and distinct mass spectra, shown in Fig. 6, which are similar to those previously published (Snyder et al., 1993). $\alpha$-Tocopherol shows a molecular ion at $m / z 430$ and a base peak at $m / z 165$, whereas $\gamma$ tocopherol presents a molecular ion at $m / z 416$ and a base peak at $m / z$ 151. The knowledge about the content and composition of tocopherols in grasses and forages is still limited (Kalač, 2012), and to our knowledge this is the only report on the composition of tocopherols in sugarcane residues. Among all tocopherols, $\alpha$-tocopherol has the highest biological activity and is the most abundant vitamin E form in nature.

\subsubsection{Steroid and triterpenoid compounds}

Different families of steroid compounds were identified among the lipids of sugarcane bagasse and straw, including free sterols, sterol glycosides, steroid ketones and steroid hydrocarbons. Free sterols were prominent in sugarcane straw (accounting for $215 \mathrm{mg} / \mathrm{kg}$ ) but occurred only in minor amounts in sugarcane bagasse $(40 \mathrm{mg} / \mathrm{kg})$. Among the free sterols identified, sitosterol $(\mathbf{X})$ was the most abundant in both samples, accounting for $12 \mathrm{mg} / \mathrm{kg}$ in bagasse and $100 \mathrm{mg} / \mathrm{kg}$ in straw. Other sterols identified were campesterol (XI), campestanol (XII), stigmasterol (XIII), stigmastanol (XIV) and 7-oxositosterol (XV). Sitosterol and stigmasterol have already been reported as being the major sterols in different parts of different sugarcane cultivars, including stalks and leaves (Deshmane and Dev, 1971; Feng et al., 2014a, 2014b). However, other sterols found in minor amounts among the extracts of sugarcane wax, such as fucosterol, gramisterol, stigmast-7-en-3ol, stigmasta-4,6,22-trien- $3 \alpha$-ol, or cholest-8(14)-en-3 $\beta$-ol acetate (Feng et al., 2014b), could not be detected among the acetone extracts of the sugarcane bagasse and straw selected for this study. 

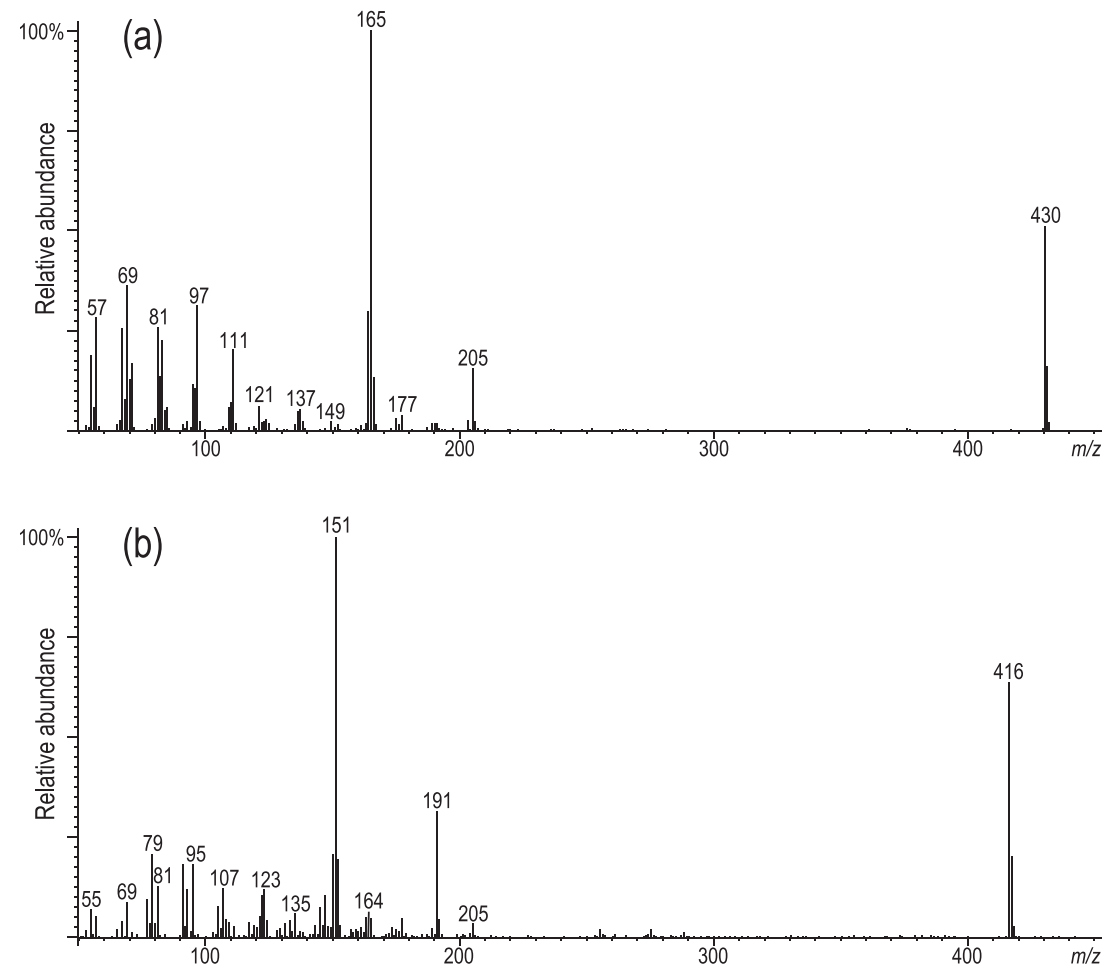

Fig. 6. Mas spectra of underivatized (a) $\alpha$-tocopherol, and (b) $\gamma$-tocopherol, identified among the lipophilic extractives of sugarcane bagasse and straw.

Sterols conjugated with carbohydrates forming sterol glycosides were also identified among the lipophilic extractives in sugarcane bagasse and straw by comparison with the mass spectra and relative retention times of authentic standards (Gutiérrez and del Río, 2001), although in minor amounts $(8 \mathrm{mg} / \mathrm{kg}$ in bagasse and $30 \mathrm{mg} / \mathrm{kg}$ in straw). Sitosteryl $3 \beta$-D-glucopyranoside (XVI) was the most predominant sterol glycoside in bagasse and straw $(5 \mathrm{mg} / \mathrm{kg}$ in bagasse and $25 \mathrm{mg} / \mathrm{kg}$ in straw) with lower amounts of campesteryl and stigmasteryl $3 \beta$-D-glucopyranosides, as usually observed in other grasses (Gutiérrez and del Río, 2001; del Río et al., 2013a, 2013b; Prinsen et al., 2012). Although sterols have been widely reported among the lipophilic compounds in sugarcane plants, to our knowledge this is the first report on the occurrence of sterol glycosides in sugarcane plant products. Different steroid ketones, namely ergost-4-en-3-one (XVII), ergostane-3,6-dione (XVIII), stigmasta-4,22-dien-3-one (XIX), stigmast-3,5-dien-7-one (XX), stigmast-4-en-3-one (XXI) and stigmastane-3,6-dione (XXII) were also identified among the lipids of sugarcane bagasse $(210 \mathrm{mg} / \mathrm{kg})$ and sugarcane straw $(285 \mathrm{mg} / \mathrm{kg})$. Similar steroid ketones were identified as components of sugarcane wax (Georges et al., 2006). Steroid hydrocarbons were also found, albeit in low amounts ( $24 \mathrm{mg} / \mathrm{kg}$ in bagasse and $46 \mathrm{mg} / \mathrm{kg}$ in straw), and included ergostatriene and stigmasta-3,5,22-triene (XXIII), the latter being the most abundant one. The important amounts of steroid compounds present in these sugarcane residues, and particularly the high content of free sterols and steroid ketones in sugarcane straw, makes this waste material an interesting and potential source for obtaining valuable phytosterols.

Finally, several triterpenoid compounds could also be identified in significant amounts in the acetone extracts from sugarcane straw (accounting for $50 \mathrm{mg} / \mathrm{kg}$ ), including taraxerol methyl ether (crusgallin, XXIV, $12 \mathrm{mg} / \mathrm{kg}$ ), arundoin (XXV, $10 \mathrm{mg} / \mathrm{kg}$ ) and isoarborinol (XXVI, $28 \mathrm{mg} / \mathrm{kg}$ ). However, only minor amounts of isoarborinol could be detected among the lipophilic extractives of sugarcane bagasse. These triterpenoids are known to occur in the culms and blades of sugarcane plant (Ohmoto et al., 1970; Deshmane and Dev, 1971).

\section{Conclusions}

A comprehensive description of the chemical composition of lipophilic phytochemicals in sugarcane bagasse and straw is presented here for the first time. The lipophilic compounds were extracted with acetone and subsequently analyzed by GC and GC-MS. The analyses revealed that the composition of lipophilic extractives is very different in sugarcane bagasse and straw. The acetone extracts from sugarcane bagasse were dominated by $n$ aldehydes (ca. $48 \%$ of all identified lipids) and $n$-fatty alcohols (ca. 23\%) with lower amounts of $n$-fatty acids (10\%) and steroid ketones (14\%), whereas the acetone extracts from sugarcane straw were strongly dominated by $n$-fatty acids (accounting for ca. $60 \%$ of all identified compounds) with significant amounts of steroid compounds, particularly sterols (10\%) and steroid ketones (14\%). Significant amounts of tocopherols and triterpenols were also found, being particularly abundant among the extractives of sugarcane straw. The amounts of the different lipophilic extractives identified in these sugarcane residues, as well as their composition, would depend on the solvent used, and therefore the figures reported in this paper may vary for other solvents. In addition, the extractives content may also vary depending of environmental and cultivation conditions such as cultivar, crop location, harvesting age or year of harvesting. The information disclosed here opens up new opportunities for the complete industrial utilization of these residues from a biorefinery perspective. Due to the large amounts of sugarcane bagasse and straw produced annually, they can be viewed as low-cost and promising sources of highly valuable phytochemicals that can be of use in the cosmetic, food or pharmaceutical industry. 
Table 2

Composition and abundance ( $\mathrm{mg} / \mathrm{kg}$ of dry, ash-free sample) of main lipids identified in the acetone extracts of sugarcane (Saccharum spp.) bagasse and straw.

\begin{tabular}{|c|c|c|}
\hline Compound & Bagasse (mg/kg) & Straw $(\mathrm{mg} / \mathrm{kg})$ \\
\hline$n$-Fatty acids & 140 & 1210 \\
\hline n-Hexadecanoic acid & 14 & 246 \\
\hline n-Heptadecanoic acid & 0 & 11 \\
\hline cis,cis-Octadeca-9,12-dienoic acid & 1 & 86 \\
\hline cis-Octadec-9-enoic acid & 2 & 210 \\
\hline n-Octadecanoic acid & 5 & 160 \\
\hline$n$-Nonadecanoic acid & 0 & 2 \\
\hline$n$-Eicosanoic acid & 8 & 75 \\
\hline n-Heneicosanoic acid & 0 & 5 \\
\hline$n$-Docosanoic acid & 4 & 50 \\
\hline$n$-Tricosanoic acid & 2 & 16 \\
\hline n-Tetracosanoic acid & 10 & 90 \\
\hline$n$-Pentacosanoic acid & 1 & 14 \\
\hline n-Hexacosanoic acid & 12 & 35 \\
\hline$n$-Heptacosanoic acid & 1 & 8 \\
\hline n-Octacosanoic acid & 60 & 160 \\
\hline$n$-Nonacosanoic acid & $\operatorname{tr}$ & 2 \\
\hline$n$-Triacontanoic acid & 15 & 20 \\
\hline$n$-Dotriacontanoic acid & 3 & 12 \\
\hline$n$-Tetratriacontanoic acid & 2 & 8 \\
\hline n-Aldehydes & 700 & 40 \\
\hline n-Docosanal & 5 & $\operatorname{tr}$ \\
\hline$n$-Tetracosanal & 7 & 1 \\
\hline$n$-Hexacosanal & 58 & 4 \\
\hline n-Octacosanal & 480 & 30 \\
\hline$n$-Triacontanal & 150 & 5 \\
\hline$n$-Fatty alcohols & 330 & 85 \\
\hline n-Tetracosanol & 12 & 4 \\
\hline$n$-Hexacosanol & 62 & 10 \\
\hline n-Octacosanol & 194 & 48 \\
\hline$n$-Triacontanol & 42 & 12 \\
\hline n-Dotriacontanol & 12 & 7 \\
\hline$n$-Tetratriacontanol & 8 & 4 \\
\hline Tocopherols & 10 & 70 \\
\hline$\alpha$-Tocopherol & 10 & 45 \\
\hline$\gamma$-Tocopherol & 0 & 25 \\
\hline n-Alkylresorcinols & 0 & 5 \\
\hline 5-n-Nonadecylresorcinol & 0 & 1 \\
\hline 5- $n$-Heneicosylresorcinol & 0 & 3 \\
\hline 5- $n$-Tricosylresorcinol & 0 & 1 \\
\hline Triterpenols & 2 & 50 \\
\hline Taraxerol methyl ether & 0 & 12 \\
\hline Arundoin & 0 & 10 \\
\hline Isoarborinol & 2 & 28 \\
\hline Sterols & 40 & 215 \\
\hline Campesterol & 9 & 25 \\
\hline Campestanol & 7 & 10 \\
\hline Stigmasterol & 6 & 30 \\
\hline Sitosterol & 12 & 100 \\
\hline Stigmastanol & 4 & 42 \\
\hline 7-Oxo-sitosterol & 2 & 8 \\
\hline Steroid hydrocarbons & 24 & 46 \\
\hline Ergostatriene & $\operatorname{tr}$ & 12 \\
\hline Stigmasta-3,5,22-triene & 24 & 34 \\
\hline Steroid ketones & 210 & 285 \\
\hline Ergost-4-en-3-one & 50 & 36 \\
\hline Ergostane-3,6-dione & 15 & 20 \\
\hline Stigmasta-4,22-dien-3-one & 46 & 52 \\
\hline Stigmasta-3,5-dien-7-one & 1 & 2 \\
\hline Stigmast-4-en-3-one & 78 & 130 \\
\hline Stigmastane-3,6-dione & 20 & 45 \\
\hline Sterol glycosides & 8 & 30 \\
\hline Campesteryl- $\beta$-D-glucopyranoside & 2 & 1 \\
\hline Stigmasteryl- $\beta$-D-glucopyranoside & 1 & 4 \\
\hline Sitosteryl- $\beta$-D-glucopyranoside & 5 & 25 \\
\hline High molecular weight esters & 5 & 8 \\
\hline Esters $\mathrm{C}_{42}$ & 1 & 2 \\
\hline Esters $\mathrm{C}_{44}$ & 3 & 4 \\
\hline Esters $\mathrm{C}_{46}$ & 1 & 2 \\
\hline
\end{tabular}

tr; trace amounts.

\section{Acknowledgements}

This study has been funded by the Spanish projects AGL201125379 and AGL2014-53730-R (co-financed by FEDER funds), the CSIC project 2014-40E-097 and the EU-project INDOX (KBBE-20137-613549). Alessandro G. Lino thanks CAPES (Coordenação de Aperfeiçoamento de Pessoal de Nível Superior) for financial support. C.F. Lima and J.L. Colodette are grateful to National Council for Scientific and Technological Development (CNPq) for research fellowships.

\section{References}

Arruzazabala, M.L., Molina, V., Mas, R., Fernández, L., Carbajal, D., Valdés, S. Castaño, G., 2002. Antiplatelet effects of policosanol (20 and $40 \mathrm{mg} /$ day) in healthy volunteers and dyslipidaemic patients. Clin. Exp. Pharmacol. Physiol. 29, 891-897.

Asikin, Y., Takahashi, M., Hirose, N., Hou, D.-X., Takara, K., Wada, K., 2012. Wax, policosanol, and long-chain aldehydes of different sugarcane (Saccharum officinarum L.) cultivars. Eur. J. Lipid Sci. Technol. 114, 583-591.

Benjamin, Y., Görgens, J.F., Joshi, S.V., 2014. Comparison of chemical composition and calculated ethanol yields of sugarcane varieties harvested for two growing seasons. Ind. Crops Prod. 58, 133-141.

Bianchi, G., 1995. Plant waxes. In: Hamilton, R.J. (Ed.), Waxes: Chemistry, Molecular Biology and Functions. The Oily Press, Dundee, Scotland, pp. 175-222.

del Río, J.C., Prinsen, P., Gutiérrez, A., 2013a. A comprehensive characterization of lipids in wheat straw. J. Agric. Food Chem. 61, 1904-1913.

del Río, J.C., Prinsen, P., Gutiérrez, A., 2013b. Chemical composition of lipids in brewerís spent grain: a promising source of valuable phytochemicals. J. Cereal Sci. 58, 248-254.

del Río, J.C., Lino, A.G., Colodette, J.L., Lima, C.F., Gutiérrez, A., Martínez, A.T., Lu, F., Ralph, J., Rencoret, J., 2015. Differences in the chemical structure of the lignins from sugarcane bagasse and straw. J. Agric. Food Chem. 81, 322-338.

de Lucas, A., García, A., Alvarez, A., Gracia, I., 2007. Supercritical extraction of long chain $n$-alcohols from sugar cane crude wax. J. Supercrit. Fluids 41, 267-271.

Deshmane, S.S., Dev, S., 1971. Higher isoprenoids-II: triterpenoids and steroids of Saccharum officinarum Linn. Tetrahedron 27, 1109-1118.

De Souza, A.P., Grandis, A., Leite, D.C.C., Buckeridge, M.S., 2014. Sugarcane as a bioenergy source: history, performance and perspectives for secong generation bioethanol. Bioenerg. Res. 7, 24-35.

Feng, S., Luo, Z., Zhang, Y., Zhong, Z., Lu, B., 2014a. Phytochemical contents and antioxidant capacities of different parts of two sugarcane (Saccharum officinarum L.) cultivars. Food Chem. 151, 452-458.

Feng, S., Luo, Z., Zhang, Y., Jiang, L., Tang, K., 2014b. Extraction optimization by response surface methodology: purification and characterization of phytosterol from sugarcane (Saccharum officinarum L.) rind. J. Sep. Sci. 37, 1308-1314

Georges, P., Sylvestre, M., Ruegger, H., Bourgeois, P., 2006. Ketosteroids and hydroxyketosteroids, minor metabolites of sugarcane wax. Steroids 71 647-652.

Goldemberg, J., 2008. The Brazilian biofuels industry. Biotechnol. Biofuels 1, 1-7.

Gunenc, A., Tavakoli, H., Setharaman, K., Mayer, P.M., Fairbanks, D., Hosseinian, F., 2013. Stability and antioxidant activity of alkylresorcinols in breads enriched with hard and soft wheat brans. Food Res. Int. 51, 571-578.

Gutiérrez, A., del Río, J.C., 2001. Gas chromatography/mass spectrometry demonstration of steryl glycosides in eucalypt wood, kraft pulp and process liquids. Rapid Commun. Mass Spectrom. 15, 2515-2520.

Gutieírrez, A., del Río, J.C., 2003. Lipids from flax fibers and their fate in alkaline pulping. J. Agric. Food Chem. 51, 4965-4971.

Gutiérrez, A., del Río, J.C., González-Vila, F.J., Martín, F., 1998. Analysis of lipophilic extractives from wood and pitch deposits by solid-phase extraction and gas chromatography. J. Chromatogr. A 823, 449-455.

Hernandez, E., 2005. Pharmaceutical and cosmetic use of lipids. In: Shahidi, F. (Ed.), Baileyís Industrial Oil and Fat Products. John Wiley \& Sons, New York, pp. 391-411.

Kalač, P., 2012. Carotenoids, ergosterol and tocopherols in fresh and preserved herbage and their transfer to bovine milk fat and adipose tissues: a review. J. Agrobiol. 29, 1-13.

Metzger, J.O., Bornscheuer, U., 2006. Lipids as renewable resources: current state of chemical and biotechnological conversion and diversification. Appl. Microbiol. Biotechnol. 71, 13-22.

Noa, M., Mas, R., 2005. Protective effect of policosanol on atherosclerotic plaque on aortas in monkeys. Arch. Med. Res. 36, 441-447.

Nuissier, G., Bourgeois, P., Grignon-Dubois, M., Pardon, P., Lescure, M.H., 2002. Composition of sugarcane waxes in rum factory wastes. Phytochemistry 61 $721-726$.

Ohmoto, T., Ikuse, M., Natori, S., 1970. Triterpenoids of the gramineae. Phytochemistry 9, 2137-2148.

Oliveira, L.R.M., Nascimento, V.M., Gonçalves, A.R., Rocha, G.J.M., 2014. Combined process system for the production of bioethanol from sugarcane straw. Ind. Crops Prod. 58, 1-7. 
Ortiz, P.S., de Oliveira, S., 2014. Exergy analysis of pretreatment processes of bioethanol production based on sugarcane bagasse. Energy 76, 130-138.

Pietarinen, S.P., Willför, S.M., Ahotupa, M.A., Hemming, J.E., Holmbom, B.R., 2006. Knotwood and bark extracts: strong oxidants from waste materials. J. Wood Sci. 52, 436-444

Prinsen, P., Gutiérrez, A., del Río, J.C., 2012. Lipophilic extractives from the cortex and pith of elephant grass (Pennisetum purpureum Schumach.) stems. J. Agric Food Chem. 60, 6408-6417.

Prinsen, P., Gutiérrez, A., Faulds, C.B., del Río, J.C., 2014. Comprehensive study of valuable lipophilic phytochemicals in wheat bran. J. Agric. Food Chem. 62, 1664-1673.

Purcell, D.E., Leonard, G.J., O'Shea, M.G., Kokot, S., 2005. A chemometrics investigation of sugarcane plant properties based on the molecular composition of epicuticular wax. Chemometr. Intell. Lab. 76, 135-147.

Rocha, G.J.M., Nascimento, V.M., Gonçalves, A.R., Silva, V.F.N., Martín, C., 2015 Influence of mixed sugarcane bagasse samples evaluated by elemental analysis and physical-chemical composition. Ind. Crops Prod. 64, 52-58.
Santos, F., Borém, A., Caldas, C., 2012. Sugarcane: Bioenergy, Sugar and Ethanol-Technology and Prospects. Universidade Federal de Viçosa, Viçosa, Brazil.

Singh, D.K., Li, L., Porter, T.D., 2006. Policosanol inhibits cholesterol synthesis in hepatoma cells by activation of AMP-kinase. J. Pharmacol. Exp. Ther. 318 1020-1026.

Snyder, J.M., Taylor, S.L., King, J.W., 1993. Analysis of tocopherols by capillary supercritical fluid chromatography and mass spectrometry. J. Am. Oil Chem. Soc. 70, 349-354.

Tulloch, A.P., 1976. Chemistry of waxes of higher plants. In: Kolattukudy, P.E. (Ed.), Chemistry and Biochemistry of Natural Waxes. Elsevier, Amsterdam, pp. 236-252.

Villaverde, J.J., de Vega, A., Ligero, P., Freire, C.S.R., Neto, C.P., Silvestre, A.J.D., 2010. Miscanthus $\mathrm{x}$ giganteus bark organosolv fractionation: fate of lipophilic components and formation of valuable phenolic byproducts. J. Agric. Food Chem. 58, 8279-8285.

Zarnowski, R., Suzuki, Y., Yamaguchi, I., 2002. Alkylresorcinols in barley (Hordeum vulgare L. distichon) grains. Z. Naturforsch. 57c, 57-62. 